\title{
Current Research: Building a Corpus of Crockett Curvilinear Incised Vessels
}

Duncan P. McKinnon

University of Central Arkansas

Follow this and additional works at: https://scholarworks.sfasu.edu/ita

Part of the American Material Culture Commons, Archaeological Anthropology Commons, Environmental Studies Commons, Other American Studies Commons, Other Arts and Humanities Commons, Other History of Art, Architecture, and Archaeology Commons, and the United States History Commons

Tell us how this article helped you.

This Article is brought to you for free and open access by the Center for Regional Heritage Research at SFA ScholarWorks. It has been accepted for inclusion in Index of Texas Archaeology: Open Access Gray Literature from the Lone Star State by an authorized editor of SFA ScholarWorks. For more information, please contact cdsscholarworks@sfasu.edu. 


\section{Current Research: Building a Corpus of Crockett Curvilinear Incised Vessels \\ Creative Commons License \\ (c) (1) \& 8}

This work is licensed under a Creative Commons Attribution-NonCommercial 4.0 International License 


\title{
Current Research: Building a Corpus of Crockett Curvilinear Incised Vessels
}

\author{
Duncan P. McKinnon \\ University of Central Arkansas
}

\begin{abstract}
As presented in an earlier report (McKinnon 2018), I have been compiling, with the help of several Caddo researchers, a comprehensive multi-state database of Caddo vessels (now close to 15,000). The on-going goal is to evaluate landscape scale social interactions and interregional relationships using this growing ceramic database. Some initial explorations have been productive in evaluating relationships between proposed Caddo communities (archaeological phases) and I suggest that these exercises have offered insights into Caddo interaction, identity, and ideological exchange in a visual and (continually) comprehensive way (McKinnon 2011, 2016).
\end{abstract}

Related, I, along with my students at the University of Central Arkansas, have been synthesizing ceramic data associated with the Bowman (3LR46) or Bowman/Wallace (3LR50) site, a Caddo multi-mound center on the Red River in Little River County, Arkansas (Hoffman 1970:167-168; McKinnon 2017; McKinnon et al. 2018; Suarez et al. 2018). Through this synthesis, several diverse examples of Crockett Curvilinear Incised vessels and sherds have been identified, which became an encouragement to start building and evaluating a corpus of this vessel type with its distinctive design.

Girard et al. (2014:54-57) highlight the frequency of the Crockett Curvilinear Incised type during the early Caddo periods and suggest that early Caddo designs likely contain symbolic referents, which have not been explored in as much detail as later Caddo ceramic types (e.g., Dowd 2011; Gadus 2013; Hart and Perttula 2010; Lambert 2018; Nash 2018). Examples of Crockett vessels are present at several Early Caddo (ca. A.D. 1050-1200) centers that likely were the "locations where social policies were formulated, decisions made, and rituals and social events carried out" (Girard et al. 2014:46). Some of these sites include George C. Davis (Newell and Krieger 1949:98-104), Bowman (Hoffman 1970:169), Crenshaw
(Schambach 1982:152), Harlan (Bell 1972, 1984), Spiro

(Brown 1996:231), and Mounds Plantation (Webb and McKinney 1975:80-81).

Crockett Curvilinear was first described in the George C. Davis report (Newell and Krieger 1949:98-101) and has been variously described in later publications (Bohannon 1973; Hoffman 1970; Suhm et al. 1954; Suhm and Jelks 1962). The vessels are carinated (early?) or globular (later?) bowls that contain incised scroll motifs executed with a high degree of variability (Newell and Krieger 1949:98-99). Commonality in design is the presence of an incised scroll motif with punctate or incised-line filled circles as the central element. An incised band frequently connects each circle, which often begins at the bottom of one circle and connects to the top of the next circle. In some cases, triangles are used as the connecting design to the circular element. The circular element is repeated around the rim or body and often contains "plain, ring-like (made with hollow reed?), or hemiconical" (Suhm et al. 1954:262) punctations in the center of the circle. Punctations or hatching (but not cross-hatching) almost always fills the enclosed spaces (see Figure 1b).

Hoffman offers the first consideration of chronology based on vessels at sites within the Little River region. In his analysis, the temporal period for the Crockett type in the Little River region begins during the early Millers Crossing phase, which "appears to have been derived stylistically from French Fork Incised at some time prior to A.D. 1000" (Hoffman 1971:578). The type is in use until the end of the Mineral Spring phase (ca. AD 1400)--a roughly 400-year span. Based on variability in shape, decoration technique, and overall design he offers type varieties associated with an evolution of vessel form and design (Table 1).

Since his chronological assessment almost 50 years ago, there has been no attempt to expand upon and evaluate the temporal and spatial characteristics 

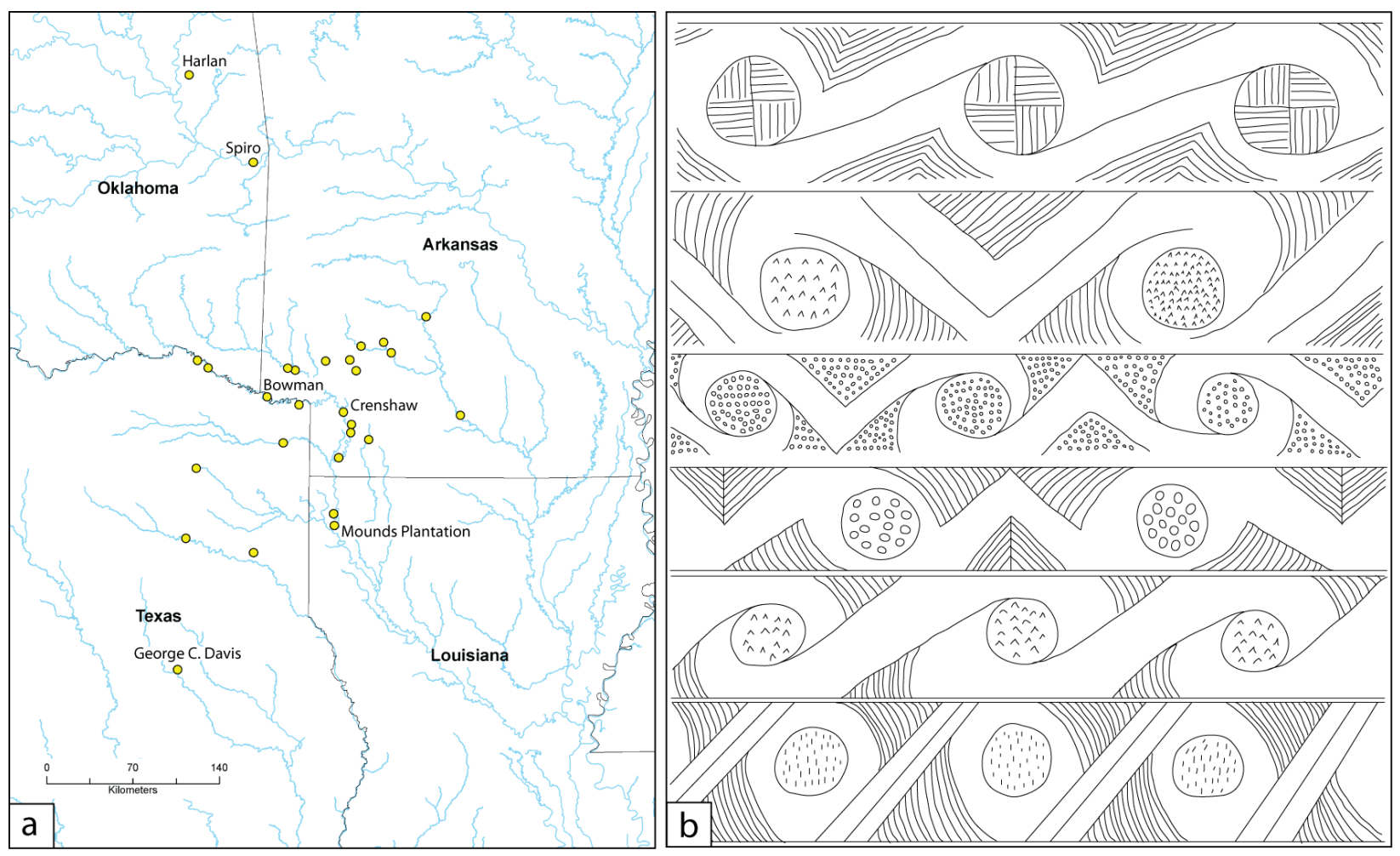

Figure 1. (a) Current distribution of Crockett Curvilinear Incised vessels in the ceramic database. (b) Examples of design variation from Crockett Curvilinear Incised vessels from the Bowman site.

\begin{tabular}{|l|l|l|l|l|}
\hline Variety & Form & Design & Sites & Phases \\
\hline $\begin{array}{l}\text { var. } \\
\text { Cossatot }\end{array}$ & $\begin{array}{l}\text { Mostly small } \\
\text { bowls with } \\
\text { straight sides or } \\
\text { with a slight } \\
\text { shoulder. }\end{array}$ & $\begin{array}{l}\text { The use of hollow } \\
\text { reed punctations. } \\
\text { Bold designs with } \\
\text { negative effect. }\end{array}$ & $\begin{array}{l}\text { Millers } \\
\text { Crossing, } \\
\text { Mineral Springs }\end{array}$ & Millers Crossing \\
\hline $\begin{array}{l}\text { var. } \\
\text { Crockettt }\end{array}$ & $\begin{array}{l}\text { Carinated bowls } \\
\text { with convex base } \\
\text { and short vertical } \\
\text { rims. }\end{array}$ & $\begin{array}{l}\text { Dots, triangle, or } \\
\text { fingernail } \\
\text { punctations. No } \\
\text { hollow reed } \\
\text { punctates. }\end{array}$ & $\begin{array}{l}\text { George C. } \\
\text { Davis, } \\
\text { Crenshaw }\end{array}$ & Alto, Lost Prairie \\
\hline $\begin{array}{l}\text { var. } \\
\text { Ozan }\end{array}$ & $\begin{array}{l}\text { Small high- } \\
\text { rimmed jars with } \\
\text { suspension holes } \\
\text { and large bowls }\end{array}$ & $\begin{array}{l}\text { Central circles filled } \\
\text { with dot, fingernail, } \\
\text { or slot punctation, } \\
\text { or hachuring. No } \\
\text { negative effect. }\end{array}$ & $\begin{array}{l}\text { Mineral Springs, } \\
\text { Bowman, East }\end{array}$ & $\begin{array}{l}\text { Late, widely } \\
\text { distributed }\end{array}$ \\
\hline $\begin{array}{l}\text { var. } \\
\text { unspecified }\end{array}$ & $\begin{array}{l}\text { Untyped sherd } \\
\text { collections }\end{array}$ & & & \\
\hline
\end{tabular}

Table 1. A summary of Little River region Crockett Curvilinear Incised varieties as suggested by Hoffman (1971:570-578). 
of Crockett forms and designs using ceramic data collected since that time. To that end, this current research summary reports on the development of a comprehensive corpus of Crockett Curvilinear Incised vessels. The goal is to evaluate variability in form and design to build upon and test the varieties first presented by Hoffman (1971). Given the possible "geographical varietal significance" (Hoffman 1971:573) of designs seemingly present in the proposed varieties, the widedistribution and presence at several influential early Caddo centers, and long duration of use during a time of the development of "complex and socially ranked societies with well-planned civic-ceremonial centers" (Perttula 2012:8), the Crockett Curvilinear Incised type (and more specifically the form and design) seems a viable candidate for evaluating ceramic variability and expression across the Caddo Area and throughout the Early Caddo time period.

As I move forward with this evaluation, I am reaching out to those who are aware of examples (and images) to build and expand the corpus. At present the database contains 142 Crockett Curvilinear Incised vessels from 27 Caddo sites and is biased toward Arkansas and Texas. Potential Louisiana and Oklahoma examples are currently underrepresented (see Figure 1a). I am interested in Crockett Curvilinear Incised examples throughout the Caddo Area (particularly Oklahoma and Louisiana) but also the distribution of similar or "hybrid" types such Pennington Punctated-Incised or French Fork Incised.

\section{References Cited}

Bell, Robert E.

1972 The Harlan Site, Ck-6, A Prehistoric Mound Center in Cherokee County, Eastern Oklahoma. Memoir 2. Oklahoma Anthropological Society, Norman.

1984 Arkansas Valley Caddoan: The Harlan Phase. In Prehistory of Oklahoma, edited by Robert E. Bell, pp. 221-240. Academic Press, Orlando.
Bohannon, Charles F.

1973 Excavations at the Mineral Springs Site, Howard County, Arkansas. Research Series No. 5. Arkansas Archeological Survey, Fayetteville.

Brown, James A.

1996 The Spiro Ceremonial Center: The Archaeology of Arkansas Valley Caddoan Culture in Eastern Oklahoma. 2 Vols. Memoir No. 29. Museum of Anthropology, University of Michigan, Ann Arbor.

Dowd, Elsbeth Linn

2011 Amphibian and Reptilian Imagery in Caddo Art. Southeastern Archaeology 39:79-95.

Gadus, Eloise F.

2013 Twisted Serpents and Fierce Birds: Structural Variation in Caddo Engraved Ceramic Bottle Motifs. Bulletin of the Texas Archeological Society $84: 215-247$.

Girard, Jeffery S., Timothy K. Perttula, and Mary Beth Trubitt

2014 Caddo Connections: Cultural Interactions Within and Beyond the Caddo World. Rowan \& Littlefield, Lanham, Maryland.

Hart, John P., and Timothy K. Perttula

2010 The Washington Square Mound Site and a Southeastern Ceremonial Complex Style Zone among the Caddo of Northeastern Texas. Midcontinental Journal of Archaeology 35:199228.

Hoffman, Michael P.

1970 Archaeological and Historical Assessment of the Red River Basin in Arkansas. In Archeological and Historical Resources of the Red River Basin, edited by Hester A. Davis, pp. 137-194. Research Series No. 1. Arkansas Archeological Survey, Fayetteville.

1971 A Partial Archeological Sequence for the Little River Region, Arkansas. Ph.D. dissertation, Department of Anthropology, Harvard University, Cambridge. 
Lambert, Shawn

2018 Addressing the Cosmological Significance of a Pot: A Search for Cosmological Structure in the Craig Mound. Caddo Archeology Journal 28:2137.

McKinnon, Duncan P.

2011 Foster Trailed-Incised: A GIS-Based Analysis of Caddo Ceramic Distribution. Caddo Archeology Journal 21:67-84.

2016 Distribution of Design: The Rayed Circle. Caddo Archeology Journal 26:29-42.

2017 A Report on a Long Term Research Program on the Bowman Site in Arkansas. Caddo Archeology Journal 27:96-97.

2018 Toward a Collaborative Development of a Truly Comprehensive Multi-State Material Culture Database. Caddo Archeology Journal 28:128-130.

McKinnon, Duncan P., Katelyn Trammell, Ryan Nguyen, and Anna Suarez

2018 An Inventory of Reconstructed Ceramic Vessels from the Bowman Site (3LR50/3LR46) in Little River County, Arkansas. Paper presented at the 60th Annual Meeting of the Caddo Archaeology Conference, Idabel, Oklahoma.

Nash, Louisa

2018 Cosmos in Clay: An Analysis of Avery Engraved Vessel Motifs. Caddo Archeology Journal 28:3859.

Newell H. Perry, and Alex D, Krieger

1949 The George C. Davis Site, Cherokee County, Texas. Memoir No. 5. Society for American Archaeology, Menasha, Wisconsin.
Perttula, Timothy K.

2012 The Archaeology of the Caddo in Southwest Arkansas, Northwest Louisiana, Eastern Oklahoma, and East Texas: An Introduction to the Volume. In The Archaeology of the Caddo, edited by Timothy K. Perttula and Chester P. Walker, pp. 1-25. University of Nebraska Press, Lincoln.

Schambach, Frank F.

1982 An Outline of Fourche Maline Culture in Southwest Arkansas. In Arkansas Archeology in Review, edited by Neal L. Trubowitz and Marvin D. Jeter, pp. 132-197. Research Series 14. Arkansas Archeological Survey, Fayetteville.

Suarez, Anna, Paula Long, and Duncan P. McKinnon

2018 A Partial Analysis of Ceramic Sherds Collected from the Bowman Site (3LR50/3LR46) in Little River County, Arkansas. Paper presented at the 60th Annual Meeting of the Caddo Archaeology Conference, Idabel, Oklahoma.

Suhm, Dee Ann, Alex D. Krieger, and Edward B. Jelks 1954 An Introductory Handbook of Texas Archaeology. Bulletin of the Texas Archeological and Paleontological Society 25:1-562.

Sum, Dee Ann, and Edward B. Jelks (editors)

1962 Handbook of Texas Archeology: Type Descriptions. Special Publication No. 1, Texas Archeological Society, and Bulletin No. 4, Texas Memorial Museum, Austin.

Webb Clarence H. and Ralph R. McKinney

1975 Mounds Plantation (16CD12), Caddo Parish, Louisiana. Louisiana Archaeology 2:39-127. 